\title{
IDENTIFICATION OF MEDICALLY-IMPORTANT DIPTERAN SPECIES IN NUWEIBA CITY, SOUTH SINAI, EGYPT, AND THEIR RELATIVE ABUNDANCE
}

\author{
Gawhara M. M. Abu El-Hassan ${ }^{1^{*}}$; Sohair M. Gad Allaha ${ }^{1}$; \\ Imam I. Ahmed ${ }^{2}$; Amina A. Rashad ${ }^{1}$; Magdi G. Shehata ${ }^{1}$ \\ ${ }^{\mathbf{1}}$ Entomology Department, Faculty of Science, Ain Shams University, Cairo, Egypt \\ ${ }^{2}$ Entomology Unit, Plant Protection Department, Desert Research Center, Cairo, Egypt
}

Article History:
Received: 12 July 2021
Revised: 16 August 2021
Accepted: 18 August 2021
Published Online:
6 September 2021
Keywords:
Dipterous
Fauna
Flies
Relative abundance
South Sinai
*Correspondence:
Gawhara M. M. Abu El-Hassan
Entomology Department
Faculty of Science
Ain Shams University
Cairo, Egypt
E-mail:
gawhara_magdy@sci.asu.edu.eg

gawhara_magdy@sci.asu.edu.eg

\begin{abstract}
Nuweiba city, South Sinai, Egypt is one of the poorly-studied areas in terms of the presence of medically-important dipteran species. Therefore, in the current study a survey of flies (order: Diptera) of medical importance in Nuweiba city was carried out during winter and summer of 2019. Six traps baited with two sources of attractants - decayed fish pieces and a ready-made botanical extract - were used to collect the flies in four selected localities. A total of 374 individuals belonging to 11 species within 9 genera under 6 families (Culicidae, Ephydridae, Ulidiidae, Calliphoridae, Muscidae, and Sarcophagidae) were captured, and the identification key was provided. The highest numbers of adult flies were found in summer in "Habiba organic farm" using traps baited with decayed fish pieces $(\mathrm{n}=159)$. Two species (Musca domestica $\mathrm{L}$. and Culex pipiens L.) were the most predominant species with a total of 141 and 100 captured specimens, respectively. The collected specimens included medically important species, as disease vectors and myiasis producers in humans and animals, which belong to three families (Calliphoridae, Muscidae, and Sarcophagidae); besides the two mosquito species (Culex pipiens and Culiseta longiareolata Macquart) that are known as vectors for many diseases of humans. In addition, Sarcophaga (Liopygia) surcoufi is newly recorded in Sinai. In conclusion, the aforementioned dipterous species may have the potential of transmitting diseases to the community dwellers in Nuweiba city; therefore, they must be controlled.
\end{abstract}

\section{INTRODUCTION}

Diptera is among the medically important insects to humans and constitutes more than 120000 described species worldwide ${ }^{[1]}$. Flies can be mechanical vectors of enteric pathogens including medically important bacteria, and they are also a major vector of important parasites including protozoa and intestinal nematodes or soil-transmitted helminthes ${ }^{[2-4]}$. Also, they can carry the viruses and fungi to humans ${ }^{[5]}$.

Mosquitoes (Diptera: Culicidae) are important vectors for a wide range of pathogenic organisms and is the deadliest animal in the world. In Egypt, many studies have been carried out to explore the presence 
of mosquitoes at several localities including the Red Sea Coast ${ }^{[6]}$, Delta governorates ${ }^{[7]}$, El Sharqiya ${ }^{[8,9]}$, El Qalyobia ${ }^{[10]}$, and El Menoufia ${ }^{[1]}$. Other studies concerned with the abundance and distribution of calliphorid and sarcophagid species in Nile Valley and Delta, Eastern and Western Deserts, and South Sinai (El Tor) were done $e^{[12-15]}$. However, in these previously mentioned studies Nuweiba city (South Sinai) is one of the areas that have not been monitored so far in terms of the presence of medically important dipterous species. Accordingly, this study is conducted to explore the dipterous insects in Nuweiba city, which have medical importance.

\section{MATERIAL AND METHODS Experimental sites}

This research was carried out in Nuweiba city in 2019 over two seasons, winter (January) and summer (July and September). Nuweiba city (Figure 1) lies on the Northeastern corner of Egypt with about $40 \mathrm{~km}^{2}$ total area. Nuweiba port was built in 1985 on the Gulf of Aqaba to support the trading and transportation between Egypt, Saudi Arabia, and Jordan. Four experimental localities were selected that represent the regions of the main daily human activity: Habiba beach lodge $\left(29^{\circ} 1^{\prime} 20.74^{\prime \prime} \mathrm{E}\right.$ and $34^{\circ} 40^{\prime} 21.20^{\prime \prime} \mathrm{N}$ ), Habiba organic farm $\left(29^{\circ} 96^{\prime} 78^{\prime \prime} \mathrm{E}\right.$ and $\left.34.66^{\circ} 96^{\prime} 33^{\prime \prime} \mathrm{N}\right)$, and some irrigation reservoirs (29 $96^{\circ} 5^{\prime \prime} \mathrm{E}$ and $\left.34.66^{\circ} 95^{\prime} 60^{\prime \prime} \mathrm{N}\right)$, both drainage canals and opened ponds of the drainage system. Nuweiba port could not be visited due to security reasons. Survey studies were carried out in the previously mentioned selected sites to record different dipterous pests in every season.

\section{Adult fly collection}

Adults were collected using traps baited with two types of attractants, decayed fish pieces and a ready-made botanical extract (ELITE Integrated Supplies, Cairo, Egypt), where each was used separately in an insect bait trap. Six traps had been built up in the agriculture habitat and animal sheds in Habiba organic farm in addition to three traps at Habiba beach lodge per each season. Traps were examined every 48 hours to collect the trapped specimens, which were then killed in jars containing tissue papers wetted with few drops of ethyl acetate. The killed specimens were pinned directly to maintain their color and texture. Small-sized specimens were preserved in $70 \%$ glycerideethanol. Finally, the specimens of each trap catchment were transferred to the laboratory for sorting and identification.

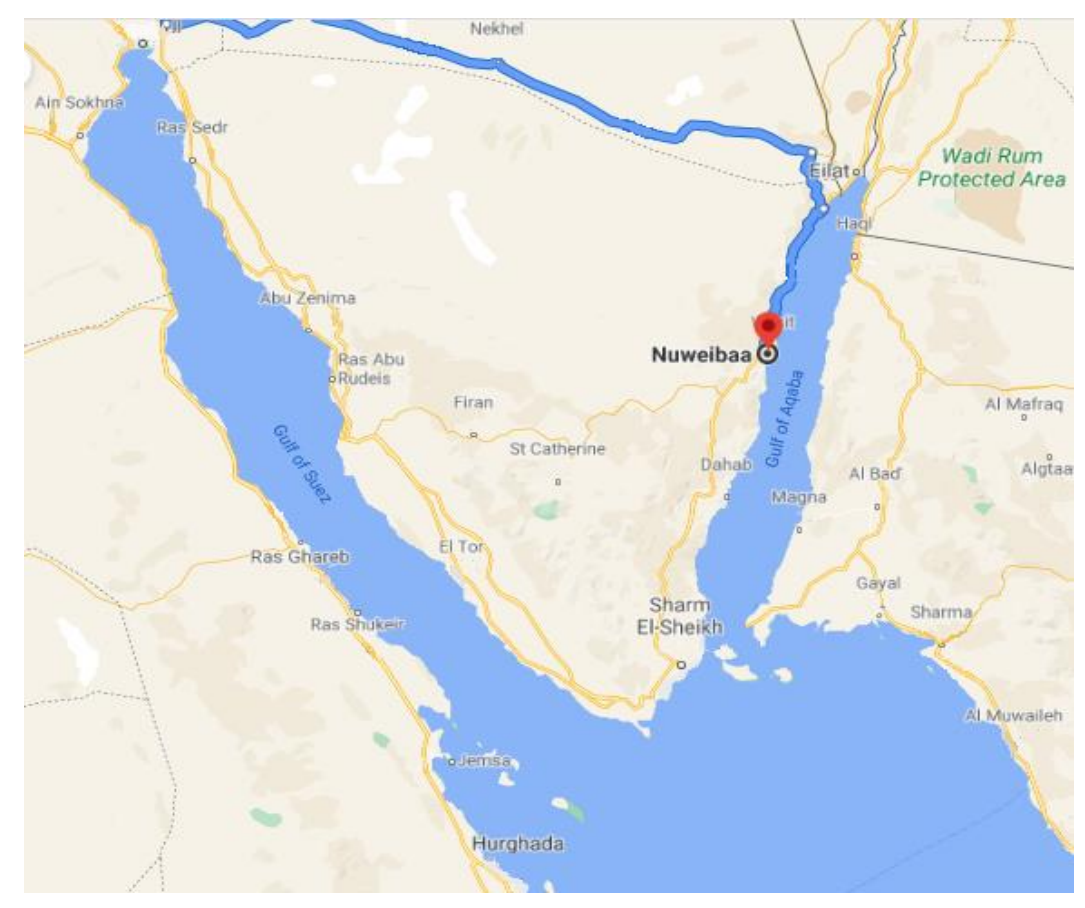

Figure 1: Map of Sinai showing Nuweiba city. 
Table (3): Numbers of collected culicid larvae and Artemia sp. using dipper and dropper technique.

\begin{tabular}{|c|c|c|c|c|}
\hline \multirow[b]{3}{*}{ Species } & \multicolumn{4}{|c|}{ Number of individuals } \\
\hline & \multicolumn{2}{|c|}{ Winter } & \multicolumn{2}{|c|}{ Summer } \\
\hline & $\begin{array}{l}\text { Drainage } \\
\text { ponds }\end{array}$ & $\begin{array}{l}\text { Irrigation } \\
\text { reservoirs }\end{array}$ & $\begin{array}{c}\text { Drainage } \\
\text { ponds }\end{array}$ & $\begin{array}{l}\text { Irrigation } \\
\text { reservoirs }\end{array}$ \\
\hline Culex pipiens & 80 & 20 & 0 & 0 \\
\hline Culiseta longiareolata & 5 & 10 & 0 & 0 \\
\hline Total number of caught individuals/season & \multicolumn{2}{|c|}{115} & \multirow{2}{*}{\multicolumn{2}{|c|}{0}} \\
\hline Total number of caught individuals & \multicolumn{2}{|c|}{115} & & \\
\hline Artemia sp. & \multicolumn{4}{|c|}{$\begin{array}{l}\sim 200 \text { individuals } / 100 \mathrm{~m} \text {. of water in } \\
\text { drainage ponds at summer season }\end{array}$} \\
\hline
\end{tabular}

Family Muscidae was the most abundant family (Figure 2) with total of 256 collected specimens during the study. A total of 206 flies, represented nine species were caught from Habiba organic farm (Habitat 2) during the survey period using the two sources of attractants, comparing with 53 flies within three species, Musca domestica, Sarcophaga (Lios.) aegyptiaca and Physiphora alceae from Habiba beach (Habitat 1) (Figure 3). Musca domestica was dominant in the two habitats as 35 and 106 flies were captured, respectively.

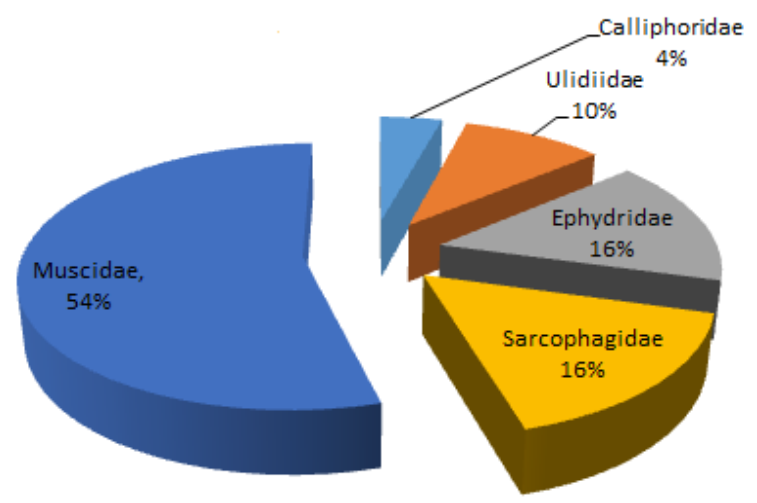

Figure 2: Abundance of dipterous families collected from Nuweiba city in 2019.

Both attractant sources that used in the present study showed variable capturing capability (Figure 4), where the potentiality of decayed fish pieces to attract genera, species, and individuals (6, 8, and 205, respectively) was more than ready-made botanical extract (3, 3, and 54 respectively).

The present results also showed a remarkable increase in the number of individuals, which entrapped during the summer season
(221 specimens) compared with those captured at the winter (38 specimens), as shown in Figure "5", with the preponderance of the decayed fish attractant in the two seasons.

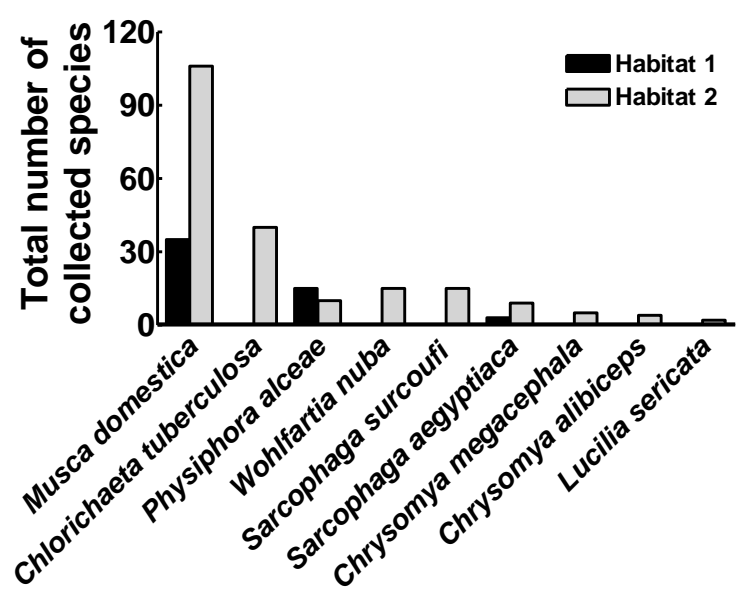

Figure 3: Total number of collected species/habitat.

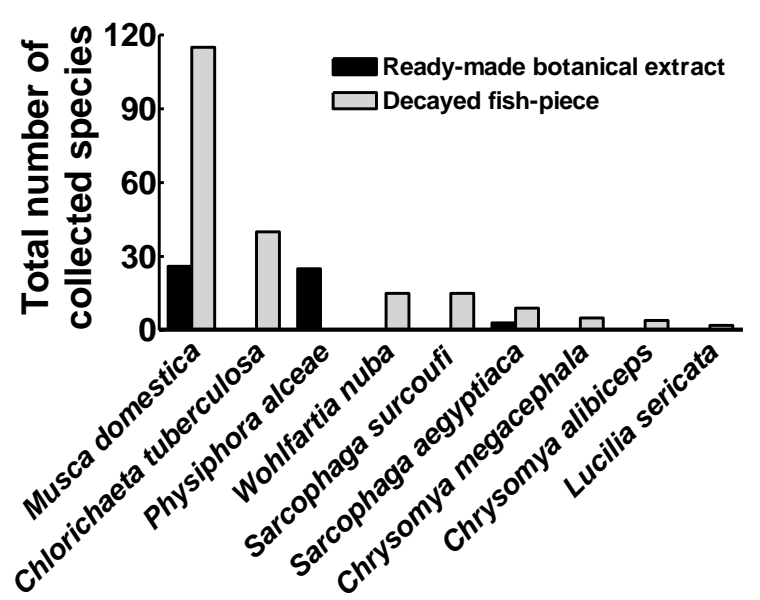

Figure 4: Total number of collected species/attractant source. 


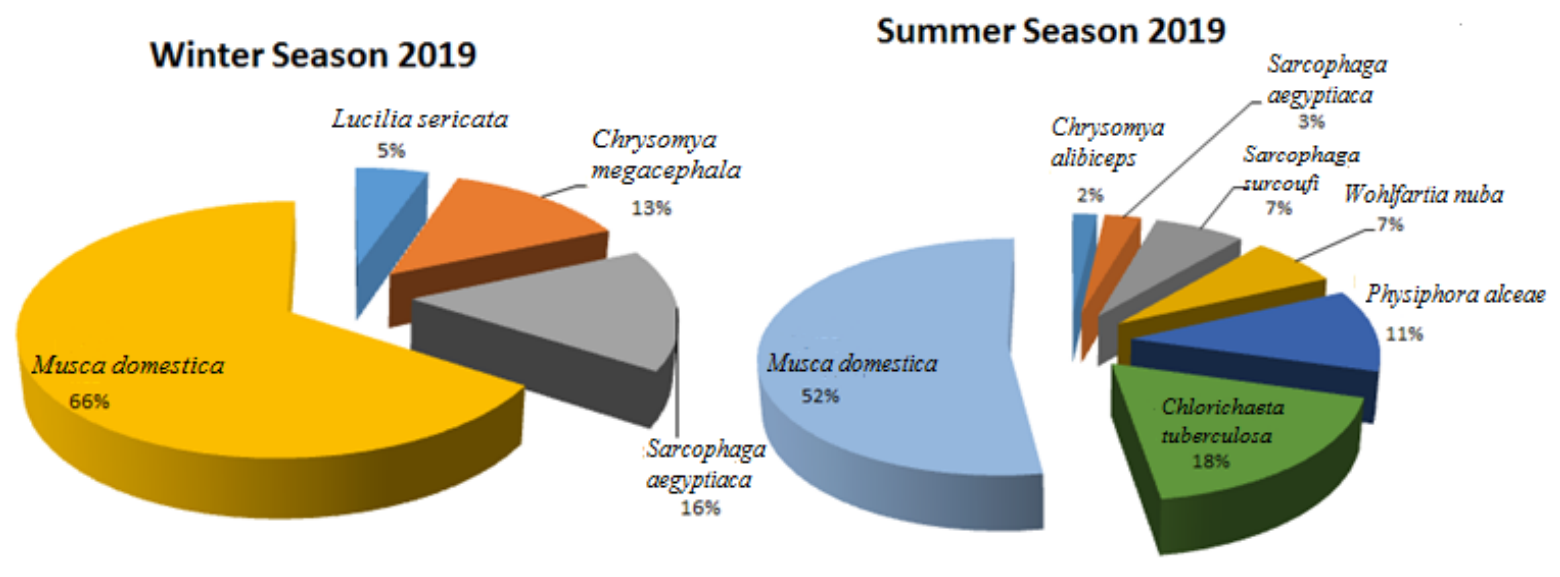

Figure 5: Abundance of dipterous species collected from Nuweiba city in 2019.

In addition, the two mosquito species were caught from the irrigation reservoirs and the drainage ponds only during winter

\section{Culex pipiens}

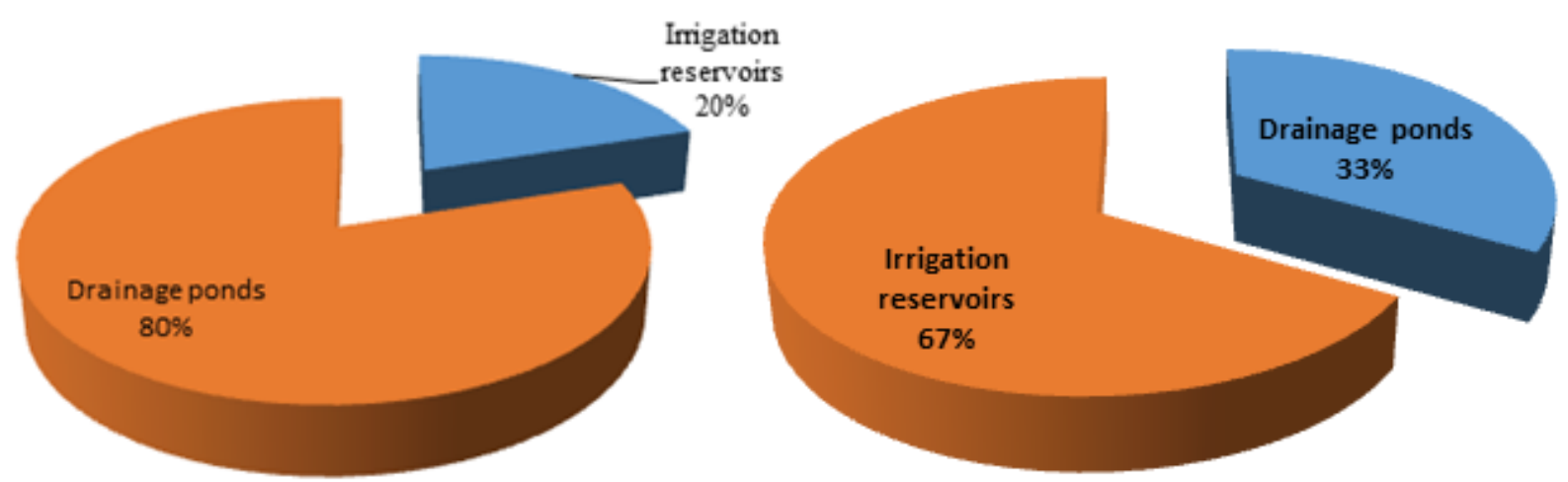

(Figure 6), and no individuals appeared at the summer.

\section{Culiseta longiareolata}

Figure 6: Relative abundance of culicid larval species/collection site.

Key to genera and species of the surveyed $4^{\text {th }}$ instar larvae of family Culicidae from Nuweiba city, South Sinai

1. Siphon with at least three pairs of seta $==\rightarrow$ Culex "Siphon/saddle index 3.45 $=\rightarrow$ Culex pipiens (Figure 7a,b)"

- Siphon with one pair of seta $==\rightarrow$ Culiseta "Pectin spines stout and widely spaced; siphon/saddle index $2.5==\rightarrow$ Culiseta longiareolata (Figure 7c,d)"

Key to families of the collected adult flies of medical importance from Nuweiba city, South Sinai

1. Antennal pedicel without dorsal cleft, calypters small or undeveloped $==\rightarrow$ Acalypetrate $==\rightarrow 2$
- Antennal pedicel with a complete dorsal cleft, calypters usually well-developed $=\rightarrow 3$

2. Costa is complete, not partially interrupted at or near tip of R1 cup cell (Figure 8f) usually with pointed or extended to posterior apex $==\rightarrow$ Ulidiidae "Eyes with dark colored stripes, frons reddish brown; wing hyaline, cell $\mathrm{r}_{4+5}$ narrowly opened; abdomen blackbrown, with purplish blue reflection; male ejaculatory apodeme wide fan like; female ovipositor prominent, with spherical spermathecae $==\vec{\rightarrow}$ [Physiphora alceae (Preyssler), Figure "8a-j"]" 


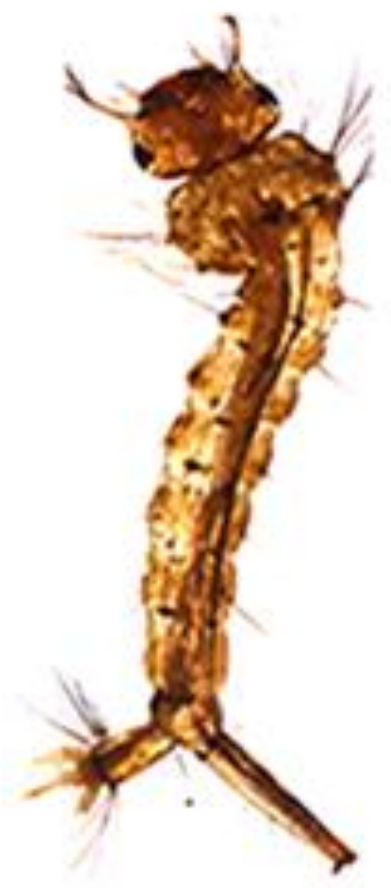

a
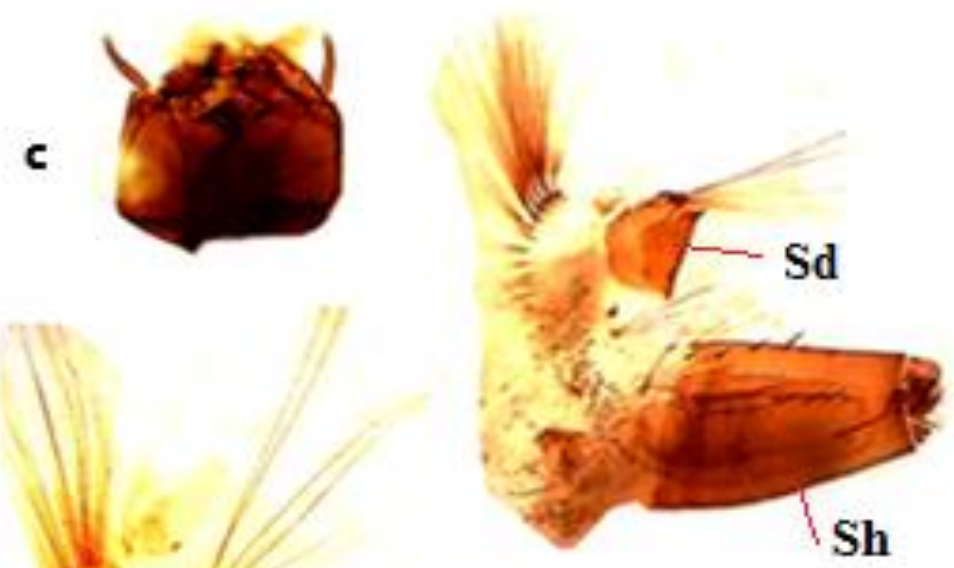

d

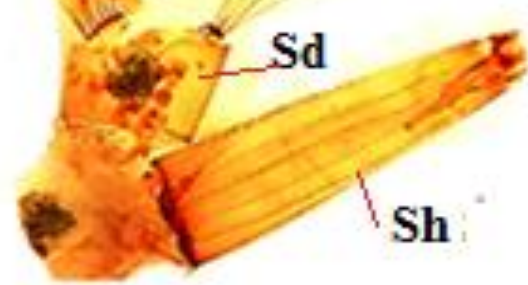

b

Figure 7: Family Culicidae: (a and b) Culex pipiens, (a) larva, (b) siphon, (c and d) Culiseta longiareolata, (c) head (dorsal view), (d) siphon. Sd: saddle, Sh: siphon.



a
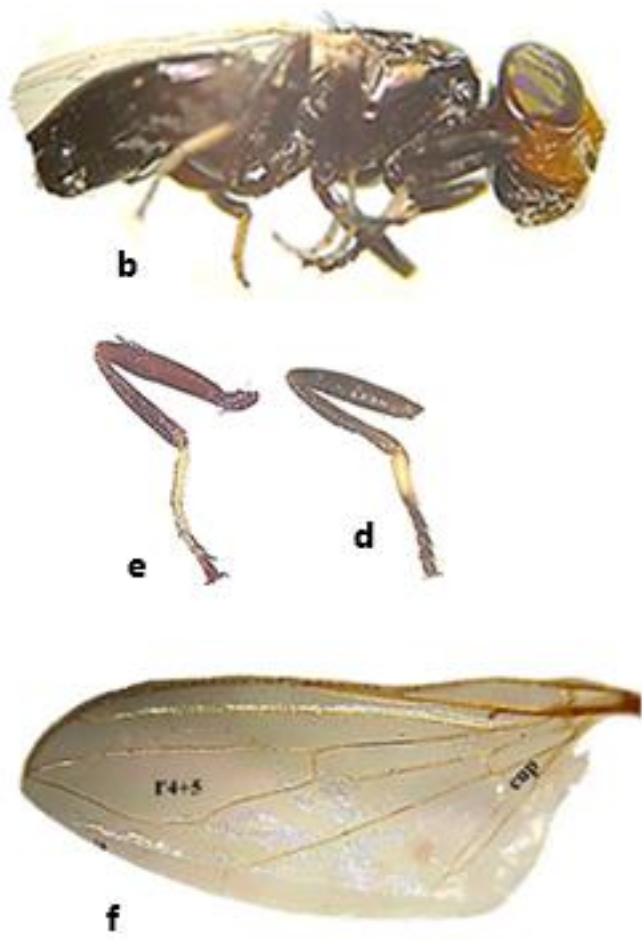

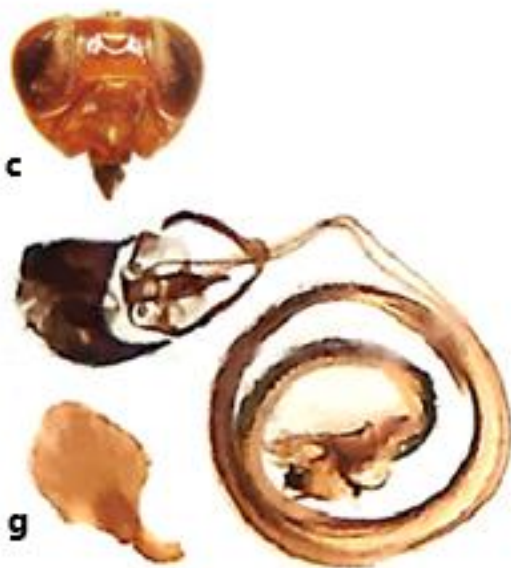

h

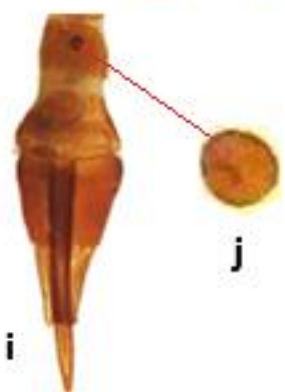

Figure 8: Family Ulidiidae, Physiphora alceae: (a and b) habitus, (a) dorsal view, (b) lateral view, (c) head, frontal view, (d) fore leg, (e) hind leg, (f) fore wing, (g) male ejaculatory apodeme, (h) male epandrium and phallus, (i) female terminalia, (j) spermathecal. 
- Costa distinctly interrupted before tip of vein R1, (Figure 9e) $==\rightarrow$ Ephydridae "Head with protruding shiny carinate face; scutellum provided with 6 marginal setae; fore femur with stout spines; length of epandrium + surstyli 1.5 times as width, lateral margins of surstylus concave towards narrowly rounded apex $==\mathbf{\rightarrow}$ [Chlorichaeta tuberculosa (Becker), Figure "9a-n"]"
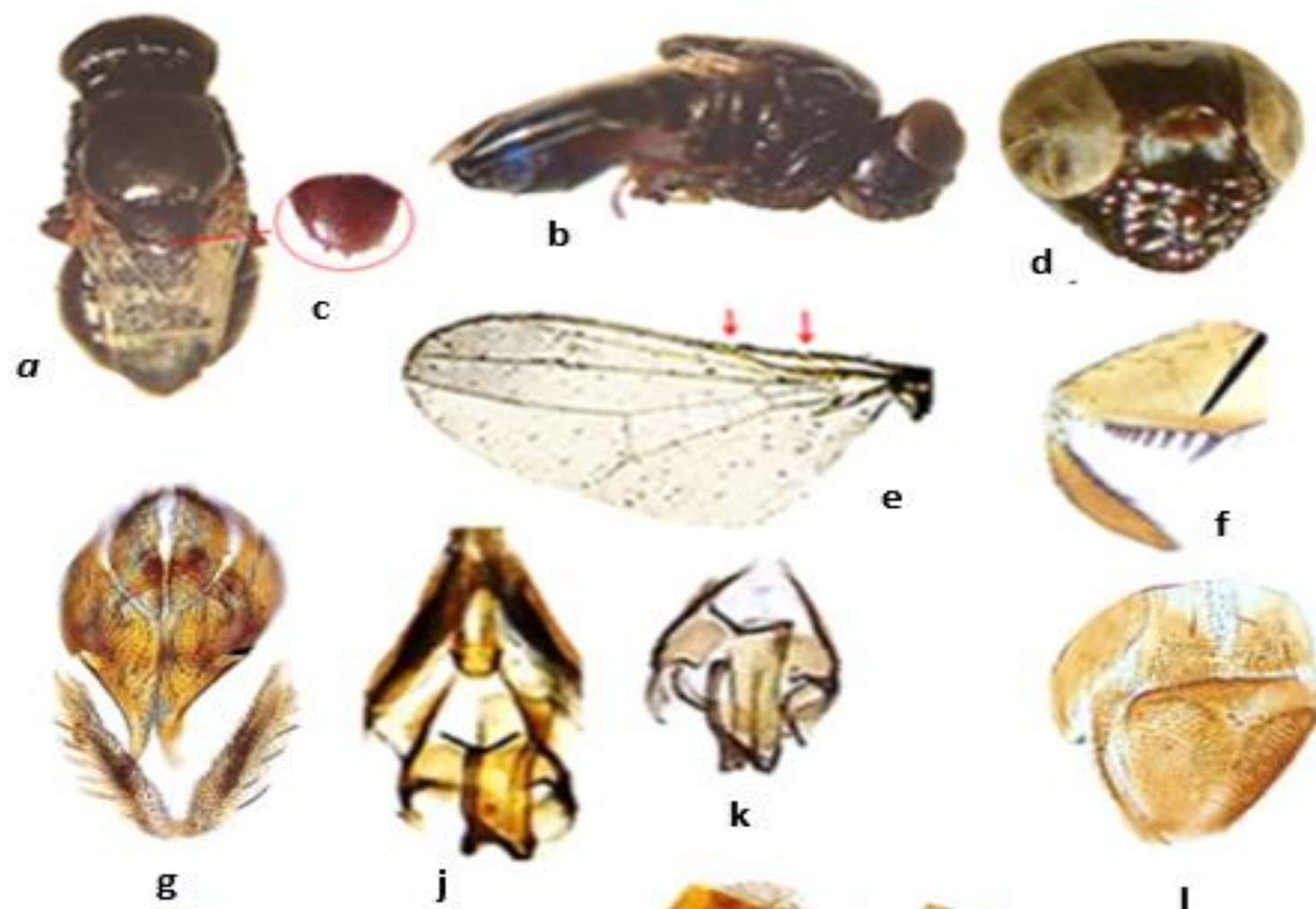

d

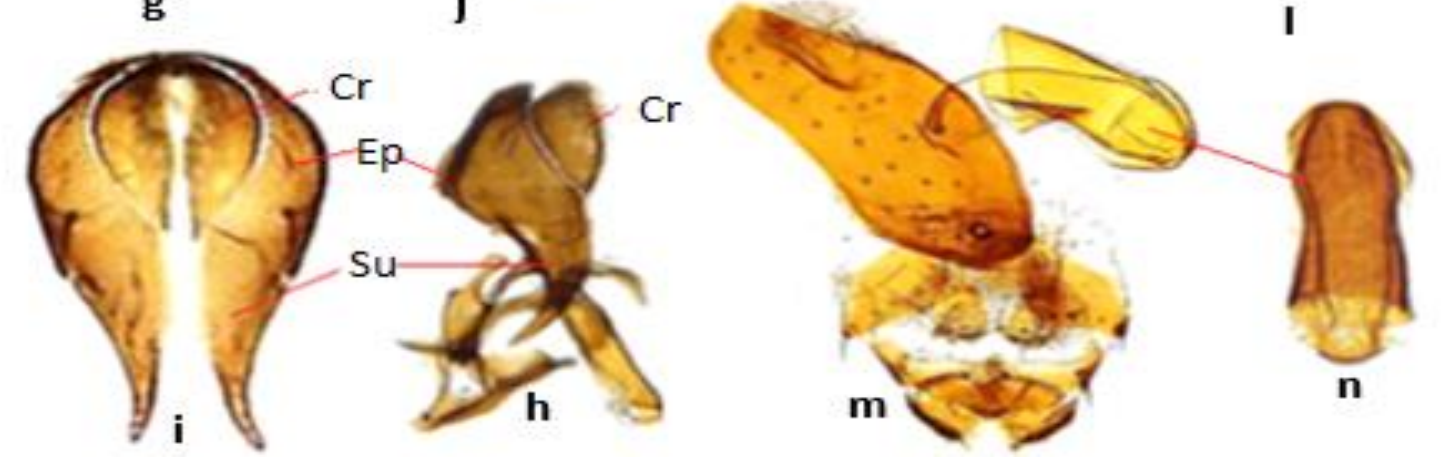

Figure 9: Family Ephydridae, Chlorichaeta tuberculosa: (a and b) habitus, (a) dorsal view, (b) lateral view, (c) scutellum showing marginal setae, (d) frontal view of head, (e) fore wing rows show interruption in costa (arrows), (f) fore femoral spines, (g-k) male genital parts, (g) dorsal view of male genitalia, (h) lateral view of male genitalia, (i) epandrium, cerci, and surstyli, (ventral view), (j and $\mathbf{k}$ ) aedeagal apodeme and aedeagus, (l and $\mathbf{m}$ ): female genital parts, (n) female spermatheca. Cr: cercus, Ep: epandrium, Su: surstylus.

3. Meron without a row of setae, rarely with scattered weak setulae $==\rightarrow$ Muscidae "Musca domestica (Linnaeus)"

- Meron with a row of setae (Figure 10a,c) $=\rightarrow 4$

4. Abdomen and usually thorax with shining metallic blue, green or bronze colors, notopleura usually with two or three setae $==\rightarrow$ Calliphoridae $==\rightarrow 5$

- Abdomen and thorax dull gray or brown, notopleura usually with four setae (two strong and two small ones) $==\rightarrow$ Sarcophagidae $==\rightarrow 7$ 
5. Base of stem vein - $\mathrm{R}$ bare above, lower calypter bare above $==\rightarrow$ Lucilia "frons at narrowest point $0.12-0.14$ as wide of head in male; $0.35-0.40$ in female; costa yellow at base; calypters white; supra squamal ridge with a cluster of setae near base of scutellum; posterior spiracles pear-shaped, thorax and abdomen completely metallic, green or bronze $==\rightarrow$ Lucilia sericata"

- Base of stem vein -R hairy above (Figure 11b); squamae hairy $==\rightarrow$ Chrysomyia $==\rightarrow 6$

6. Anterior thoracic spiracle pale whitish yellow (Figure 11d), genae totally or for the greater part yellowish, innerside of $3^{\text {rd }}$ antennal segment dark brown; eye facets of male with no clear line of demarcation between larger and smaller facets $==\rightarrow$ Chrysomyia albiceps

- Anterior thoracic spiracle pale brown
(Figure 11f), genial dilation with orange hairs, $3^{\text {rd }}$ antennal segment yellowish to orange, eye of male with upper facets much enlarged and with sharp demarcation from small facets below $==\rightarrow$ Chrysomyia megacephala

7. Abdomen with patterns forming a median strip and dark lateral spots, hind coxa bare on posterior surface $==\vec{\rightarrow}$ Wohlfahrtia "Body medium in size; 5-12 $\mathrm{mm}$ in length; gray in color; $2^{\text {nd }}$ antennal segment and palps orange color; thorax gray, with three black stripes; wing with $4^{\text {th }}$ vein sharply angled; abdomen grey with three black round spots at the end of each segment $==\rightarrow$ Wohlfahrtia nuba (Figure 10)"

- Abdomen with distinct check board patterns, hind coxae with setae on posterior surface $==\rightarrow$ Sarcophaga


Figure 10: Family Sarcophagidae: (a and b) Wohlfartia nuba, (a) habitus (lateral view), (b) head (lateral view), (c-e) Sarcophaga aegyptiaca, (c) head and thorax (lateral view), (d) abdomen (dorsal view), (e) male genitalia (lateral view), (f-h) Sarcophaga (Liopygia) surcoufi, (f) habitus (lateral view), (g) abdomen (dorsal view), (h) male genitalia (lateral view). Cr: cercus, Pt: postgonite. 


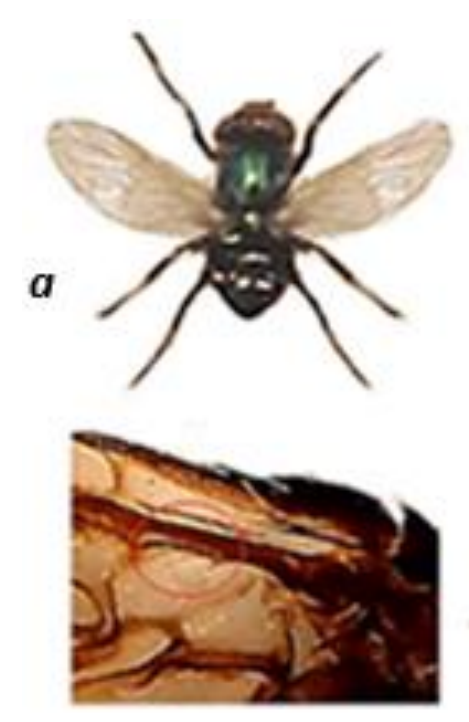

b

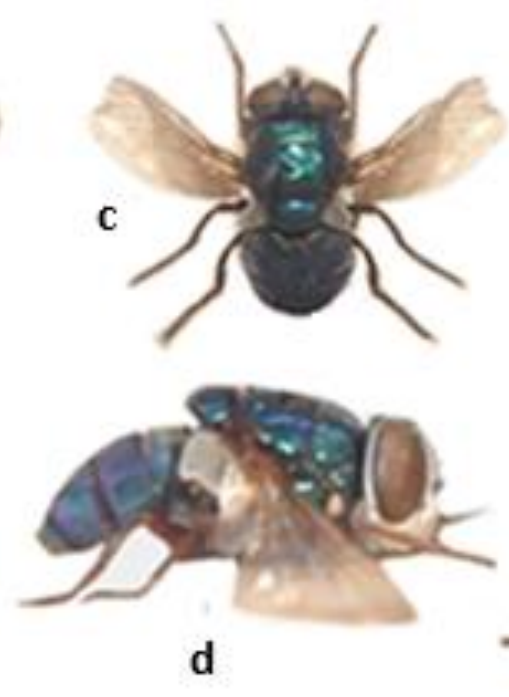

d

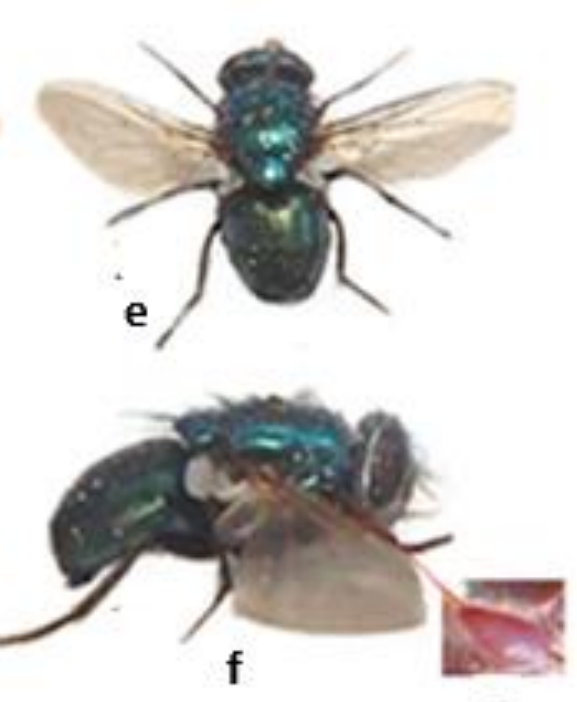

g

Figure 11: Family Calliphoridae: (a) Lucilia sericata, habitus (dorsal view), (b-d) Chrysomya alibiceps, (b) base of fore wing, (c) habitus (dorsal view), (d) habitus (lateral view), (e-f) Chrysomya megacephala, (e) habitus (dorsal view), (f) habitus (lateral view), (g) anterior spiracle.

8. Gena with white hairs, sometimes with some black hairs at anterior margin as well, Syntergo sternite $7+8$ orange, with a grey strip and setose at apical margin; parafacial setae arranged in one row closed to eye $==\rightarrow$ Subgenus Liopygia "Cerci narrow with prominence dorsally, its apical half almost as broad as postgonite; vesica with a long arm $==\rightarrow$ S. (Liop) surcoufi (Figure 10f-h)"

- Gena with black hairs at anterior half and white hairs at posterior half; Syntergo sternite $7+8$ grey at apical half and brown at basal half, without setae at apical margin $==\rightarrow$ Subgenus Liosarcophaga "Epandrium orange; vesica sclerotised, dark, with two short processes apically $==\rightarrow$ S. (Lios.) aegyptica (Figure 10c-e)"

\section{DISCUSSION}

This study represented an updated knowledge to the fauna of the dipteran insects, which have medical and veterinary importance in Nuweiba city (South Sinai) that is considered as a commercial center. According to the results obtained from this research eleven species belonging to nine genera within six families (Culicidae,
Ephydridae, Ulidiidae, Calliphoridae, Muscidae, and Sarcophagidae) were collected during the two seasons (summer and winter 2019). The results of the present study revealed that there was a marked difference in the density of the caught medically important flies according to the nature of habitat, attractant sources, and inventory season. On this matter, the present results explain that both attractant sources showed variable capturing ability. This variation in entrapment ability may be due to the different active ingredients that emitted from the two attractants. The effectiveness of the decayed fish pieces source to attract dipterous species of medical importance was also previously mentioned $^{[14]}$. It is clear that the survey season and the place where the traps got installed may present more suitable harbor for one or some species than others. Among the captured species, only the two species Musca domestica and Sarcophaga (Lios.) aegyptiaca were trapped by both attractants, where the composites released from both attractants were successful to attract muscid and sarcophagid species, while the remaining attracted to the fragrances 
emitted from only one of the tested attractants.

Regarding the surveyed habitats, the high number of Musca domestica that collected from Habiba organic farm may be due to the availability of oviposition and breeding sites, as plant remnants or leftovers in addition to animal droppings or dung. Also, these conditions in Habiba farm may possibly be the main reason for the high abundance of the veterinary important calliphorid and sarcophagid species. In addition, The greater number of specimens, which collected in the summer season, might be due to the faster growth rates and the shortening of the developmental intervals of the immature stages of the flies ${ }^{[32]}$.

The dipper and dropper technique was used to collect and track the seasonal abundance of mosquito larvae. As a result, two mosquito species under two genera belonging to family Culicidae were collected besides Artemia sp., brine shrimp (Class: Branchiopoda, Family: Artemiidae). The two mosquito species were caught only during winter this may be due to the appropriateness of the water as an oviposition and breeding sites for the immature stages of mosquito in the winter. The high temperature as well as the high evaporation rate of water bodies in Nuwebia city during the summer may possibly be the main reasons of water unsuitability, and therefore forming the obstacles for the population growth of the mosquitoes. Worthy of note is that no species belonging to genus Anopheles, the main vector of malaria, was caught throughout the study. This may be due to the lack of suitable breeding sites/habitat for this mosquito species. Also, Artemia sp. was highly dominant in the drainage ponds during summer.

The different abundant patterns of mosquito larvae might be explained by go over the characteristics of their habitat. In this regard, $C$. pipiens were collected from both irrigation reservoirs and drainage ponds that agree with our data ${ }^{[8,11,20,33]}$. In contrast, the larvae of $C x$. longiareolata are mainly lived in small fresh water lakes ${ }^{[8]}$. The finding of $C x$. longiareolata in drainage ponds might be due to the relative enhancement of the properties of the drainage water by the overflowed water during the flooding season. This running water can refresh the drainage water and dilute the concentration of the sludge or settled it down thus being a suitable habitat for these mosquitos' larvae. The finding of Artemia sp. in summer season was of quite different than the case of mosquito larvae. The life behavior of this species might help for explanation. The Artemia sp. is adapted to alive in the excessive saline lakes; consequently it is act as a biological indicator for detecting the potential hazardous chemicals in the water samples ${ }^{[34]}$. The high evaporation rate in the opened drainage ponds of Nuwebia city during summer season may concentrate the salinity of the water, making it a proper habitat for Artemia sp.

Regarding the role played by the collected species as disease vectors and myiasis producers, Wohlfahrtia nuba was stated as an occasional secondary invader of wounds in camel then can cause severe myiasis. The two species, Chrysomya albiceps and $C$. megacephala, are also related to myiasis. Furthermore, the later species act as a potential vector of many diseases owing to its close association with human housing; equally it considered being a potential mechanical vector of fecal pathogens. Also, Lucilia sericata causes myiasis in sheep and is a vector for pathogens. Physiphora alceae can transmit various disease-causing organisms to food material and can reproduce in human corpses $^{[27,30,35,36]}$. As well, Musca domestica is a mechanical or biological vector of many human pathogens and parasites such as typhoid, cholera, dysentery diseases; also it cause accidental myiasis of intestine and urinogenital Trachoma virus, leprosy, tuberculosis, and enteric infections...etc ${ }^{[18,37,38]}$. In addition, both Culex pipiens and Culiseta longiareolata have been indicated as vectors of several 
diseases $^{[39]}$. In conclusion, since the aforementioned dipterous species have the potential of transmitting disease, it could constitute a health risk to the community dwellers in Nuweiba city and must be controlled.

\section{AUTHORS' CONTRIBUTIONS}

SMG, MGS, and IIA conceived and designed research; IIA and AAR collected the specimens; SMG, GMMA, and AAR identified and dissected the collected specimens, writing-original draft; GMMA final editing and formatting. All authors have read and agreed to the published version of the manuscript.

\section{FUNDING SOURCE DISCLOSURE}

This research received no specific grant from any funding agency in the public, commercial, or not-for-profit sectors.

\section{CONFLICT OF INTEREST}

The authors have no potential financial conflict of interest.

\section{REFERENCES}

[1] Service M. (2008). Medical Entomology for Students. Cambridge University Press, Cambridge, UK.

[2] El-Sherbini, G. T. and Gneidy, M. R. (2012). Cockroaches and flies in mechanical transmission of medically important parasites in Khaldyia Village, El Fayoum, Governorate, Egypt. J Egypt Soc Parasitol, 42: 165-174.

[3] Fetene, T. and Worku, N. (2009). Public health importance of non-biting cyclorrhaphan flies. Trans R Soc Trop Med Hyg, 103(2): 187-191.

[4] Sukontason, K. L.; Bunchoo, M.; Khantawa, B. et al. (2007). Comparison between Musca domestica and Chrysomya megacephala as carriers of bacteria in northern Thailand. Southeast Asian J Trop Med Public Health, 38: 38-44.

[5] Junqueira, A. C. M.; Ratan, A.; Acerbi, E. et al. (2017). The microbiomes of blowflies and houseflies as bacterial transmission reservoirs. Sci Rep, 7: 16324 (DOI: 10.1038/s41598-017-16353-x).

[6] Gad, A. M.; Harbach, R. E. and Harrison, B. A. (2006). Anopheles (Cellia) ainshamsi (Diptera: Culicidae), a salt water species from the Red Sea coast of Egypt. Proc Entomol Soc Wash, 108: 366-380.

[7] El-Said, S.; Kenawy, M. A. and Gad, A. M. (1983). Field studies on anopheline mosquito larvae in Egypt (Diptera: Culicidae). V. Association of anopheline larvae with other mosquito species in the some breeding place. J Egypt Pub Health Assoc, 58: $1-45$.

[8] Kenawy, M. A.; Rashed, S. and Teleb, S. (1996). Population ecology of mosquito larvae (Diptera: Culicidae) in Sharkiya governorate, Egypt. J Egypt Ger Soc Zool, 21: 121-142.

[9] Abdel-Hamid, Y. M.; Soliman, M. I. and Allam, K. M. (2009). Spatial distribution and abundance of culicine mosquitoes in relation to the risk of filariasis transmission in El Sharqiya governorate, Egypt. Egypt Acad J Biolog Sci, 1: 39-48.

[10] Hilmy, N.; Merdan, A. and Ibrahim, A. (1987). Mosquito distribution in Qalyubiya governorate, Egypt. J Egypt Soc Parasitol, 17(1): 223-231.

[11] Abdel-Hamid, Y. M.; Soliman, M. I. and Kenawy, M. A. (2011). Geographical distribution and relative abundance of culicine mosquitoes in relation to trans-mission of lymphatic filariasis in El Menoufia governorate, Egypt. J Egypt Soc Parasitol, 41: 109118.

[12] Mohamed, S. and Abdel-Rahman, H. (1982). Seasonal abundance of Sarcophagidae (Diptera) in two localities in Egypt. Bull Entomol Soc Egypt, 64: 89-94.

[13] Shaumar, N.; Mohamed, S. and Shoukry, I. (1985). Flies of subfamily muscinae (Muscidae, Diptera) in 
Egypt. J Egypt Soc Parasitol, 15(2): 513-523.

[14] Amin, A.; Morsy, T.; Shoukry, A. et al. (1998). Studies on myiasis producing flies collected by bait traps at Al-Marg (Qalyobia governorate), Egypt. J Egypt Soc Parasitol, 28: 4551.

[15] Morsy, T.; Fayad, M.; Salama, M. et al. (1991). Some myiasis producers in Cairo and Giza abattoirs. J Egypt Soc Parasitol, 21(2): 539-546.

[16] Barraud, P. (1934). The Fauna of British India Including Ceylon and Burma. Diptera. Volume V. Family Culicidae. Tribes Megarhinini and Culicini. Taylor and Francis, London, UK.

[17] Zumpt, F. and Heinz, H. (1950). A contribution of the study of the morphology and homology of the male termination of Calliphora and Sarcophaga (Diptera: Calliphoridae). Entomol Mon Mag, 86: 207-217.

[18] Greenberg, B. (1971). Flies and Disease. I. Ecology, Classification, and Biotic Associations. Princton University Press, Princton, NJ, USA.

[19] Harbach, R. E. (1985). Pictorial keys to the genera of mosquitoes, subgenera of Culex and the species of Culex (Culex) occurring in Southwestern Asia and Egypt, with a note on the sub-generic placement of Culex deserticola (Diptera: Culicidae). Mosquito Systematic, 17(2): 83-107.

[20] Harbach, R. E. (1988). The mosquitoes of the subgenus Culex in Southwestern Asia and Egypt (Diptera: Culicidae). Contrib Amer Ent Inst, 24: 1-240.

[21] Shaumar, N.; Mohamed, S. and Mohamed, S. (1989). Keys for identification of species of family Calliophoridae (Diptera) in Egypt. J Egypt Soc Parasitol, 19: 669-681.

[22] Chen, X.-L. and Kameneva, E. P. (2007). A review of Physiphora Fallén (Diptera: Ulidiidae) from China. Zootaxa, 1398: 15-28.
[23] Ebrahim, A.; El-Hawagry, M.; Negm, F et al. (2007). Key to tribes, genera, and species of the subfamily Gymnomyzinae (Ephydridae, Diptera) from Egypt, with description of a new species. Proc $2^{\text {nd }}$ Inter Conf Entmol Soc Egypt, 1: 253-266.

[24] Whitworth, T. (2010). Keys to the genera and species of blow flies (Diptera: Calliphoridae) of the West Indies and description of a new species of Lucilia Robineau-Desvoidy. Zootaxa, 2663: 1-35.

[25] Harbach, R. E. (2011). Classification within the cosmopolitan genus Culex (Diptera: Culicidae): The foundation for molecular systematics and phylogenetic research. Acta Trop, 120(1-2): 1-14.

[26] Harbach, R. E. (2013). Mosquito Taxonomic Inventory (http://mosquitotaxonomic-inventory.info/).

[27] Irish, S.; Lindsay, T. and Wyatt, N. (2014). Key to adults of Afrotropical species of the genus Chrysomya Robineau-Desvoidy (Diptera: Calliphoridae). Afr Entomol, 22(2): 297-306.

[28] Gonzalez, C.; Lianos, L.; Oses, C. et al. (2017). Calliphoridae from Chile: key to the genera and species (Diptera: Oestroidea). Anales Instituto Patagonia (Chile), 45(3): 19-27.

[29] El-Ahmady, A.; Taha, M.; Soliman, A. M. et al. (2018). A new species and new records of the genus Sarcophaga from Egypt, with a key to the known Egyptian species (Diptera: Sarcophagidae). Afr Entomol, 26(2): 507-521.

[30] Alikhan, M.; Al Ghamdi, K.; Mahyoub, J. A. et al. (2018). Public health and veterinary important flies (order: Diptera) prevalent in Jeddah Saudi Arabia with their dominant characteristics and identification key. Saudi J Biol Sci, 25(8): 1648-1663.

[31] Evenhuis, N. L.; Pape, T.; Pont, A. C. et al. (2008). BioSystematic Database of World Diptera. Status 
Report Version 10.5 (http://www. diptera.org).

[32] Al Ahmed, A. M.; Al Kuriji, M. A.; Kheir, S. M. et al. (2010). Distribution and seasonal abundance of mosquitoes (Diptera: Culicidae) in the Najran Region, Saudi Arabia. Stud Dipterol, 17: 13-27.

[33] Salit, A. M.; Al-Tubiakh, S. S.; El-Fik, S. A. et al. (1996). Physical and chemical properties of different types of mosquito aquatic breeding places in Kuwait State. Proc $2^{\text {nd }}$ Int Conf Urban Pests, 185-193.

[34] Gajardo, G. M. and Beardmore, J. A. (2012). The brine shrimp Artemia: adapted to critical life conditions. Front Physiol, 3: 185 (DOI: 10.3389/ fphys.2012.00185).

[35] Hall, M. J. R.; Adams, Z. J. O.; Wyatt, N. P. et al. (2009). Morphological and mitochondrial DNA characters for identification and phylogenetic analysis of the myiasis-causing flesh fly Wohlfahrtia magnifica and its relatives, with a description of Wohlfahrtia monegrosensis sp. $\mathrm{n}$.
Wyatt \& Hall. Med Vet Entomol, 23: 59-71.

[36] Al-Ghamdi, K. M.; Alikhan, M.; Mahyoub, J. A. et al. (2015). Characterization of forensically important necrophagous flies (Diptera) of Jeddah, Saudi Arabia. Adv Environ Biol, 9(8): 58-71.

[37] Patton, W. S. and Cushing, E. C. (1934). Studies on the higher dipteral of medical and veterinary importance. A revision of the genera of subfamily calliphorinae based on a comparative study of the male and female terminalia: the Genus Phormia Robineau-Desvoidy (sens. lat.). Ann Trop Med Parasit, 28: 123-130.

[38] Zumpt, F. (1965). Myiasis in Man and Animals in the Old World: A Textbook for Physicians, Veterinarians and Zoologists. Butterworth \& Co. (Publishers) Ltd., London, UK.

[39] Bergquist, N. R. (2001). Vector-born parasitic diseases: new trends in data collection and risk assessment. Acta Trop, 79: 13-20.

\section{How to cite this article:}

Abu El-Hassan, G. M. M.; Gad Allaha, S. M.; Ahmed, I. I.; Rashad, A. A. and Shehata, M. G. (2021). Identification of medically-important dipteran species in Nuweiba city, South Sinai, Egypt, and their relative abundance. Egyptian Journal of Zoology, 76: 52-65 (DOI: 10.21608/ejz.2021.82773. 1059). 


\title{
تعيين أنواع ثنائيات الأجنحة ذات الأهمية الطبية في مدينة نويبع، جنوب سيناء، مصر ونسب شيوعها
}

\author{
جوهرة مجدي محمد أبوالحسن1، سهير محمد جادالله1، أحمد إبراهيم إمام²، أمينة عبدالعزيز رشاد1، \\ مجدي جبريل شحاتة 1 \\ 1قفم علم الحشر ات، كلية العلوم، جامعة عين شمس، القاهرة، جمهورية مصر العربية

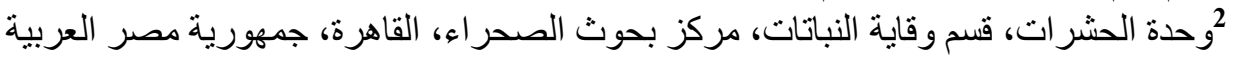

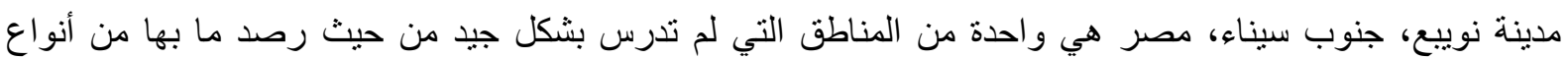

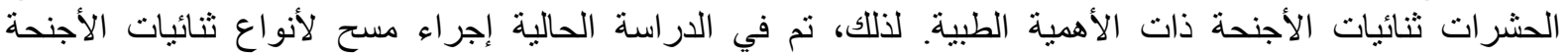

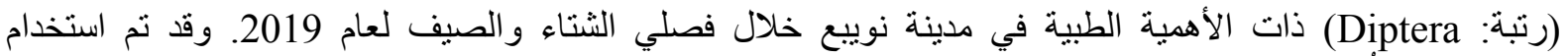

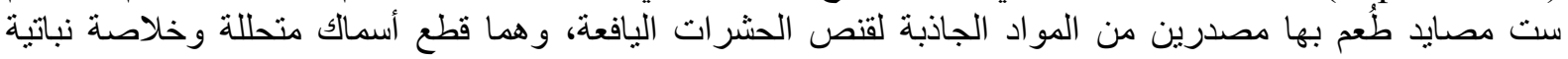

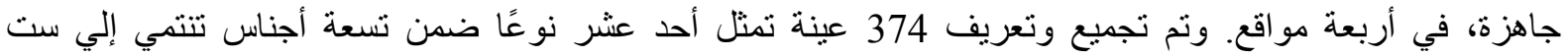

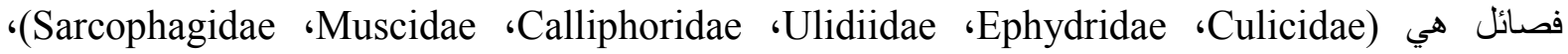

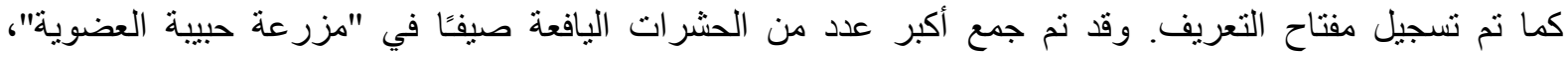

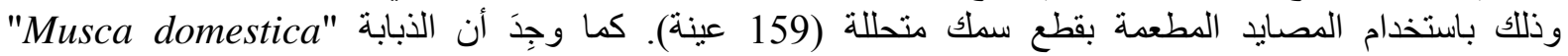

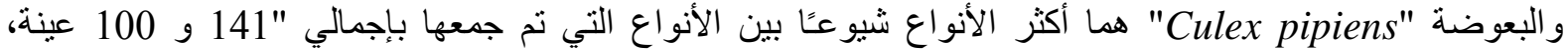

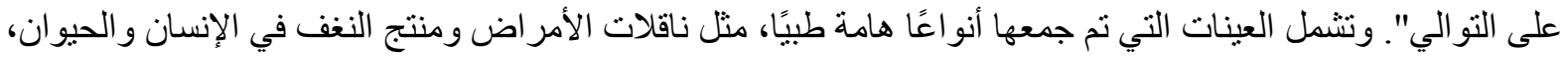

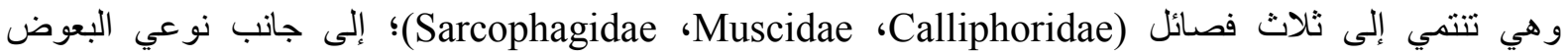
"Culiseta longiareolata و Culex pipiens" المعروفين كنواقل للعديد من الأمراض التي تصيب الإنسان. وقد أضافت الدراسة النوع "Sarcophaga (Liopygia) surcoufi" إلى المجموعة الحشرية في سيناء. وتستنتج

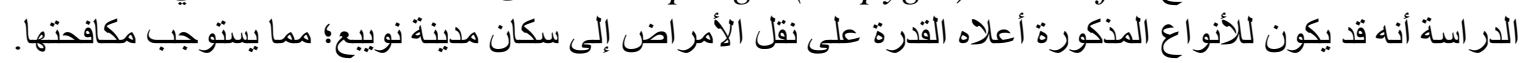

